\title{
DEVELOPMENT OF QUR'AN AND HADITH-BASED MATHEMATICS MODULE FOR STUDENTS' MATHEMATICAL UNDERSTANDING AND RELIGIOUS CHARACTER
}

\author{
Choirudin'1a, Agus Setiawan'b, M. Saidun Anwar1c, Eka Riyana1d \\ M. Sayyidul Abrori1e, Wahyudi1f \\ ${ }^{1}$ Institut Agama Islam Ma'rif NU (IAIMNU) Metro Lampung, Lampung, Indonesia \\ achoirudiniaimnumetro@gmail.com, b4905as@gmail.com, \\ csaidun.anwar@gmail.com, dekariyana732@gmail.com, \\ earori400@gmail.com, fwahyudiragi447@gmail.com
}

\begin{abstract}
The module is a means of delivering material to students and a supporting tool in the learning process. The teaching materials used are also expected to be able to build the values and morality of each student through learning the integration of science and religion, one of which is by using teaching materials based on the Qur'an and Hadith. This study aims to develop teaching materials in mathematics learning in the form of modules based on the Qur'an and Hadith. This type of research is research and development using the Borg \& Gall development model. The development of the module is carried out on the fractional number material for class VII Islamic Junior High School (MTs). The data collection instruments used in this study were a questionnaire from media experts, material experts, and religious experts who were used to test the quality of the mathematics module based on the Qur'an and Hadith, as well as a questionnaire response from educators and students who were used to test interest in the developed module. Data collection methods used in this study are interviews, documentation, and questionnaires. This research produces a product in the form of a mathematical module based on the Qur'an and Hadith. In learning using a mathematics module based on the Qur'an and Hadith in grade VII Takhasus MTs Hidayatul Mubtadiin, Dayamurni can improve students' mathematical understanding and can shape students' religious attitudes.
\end{abstract}

Keywords: Qur'an and Hadith, Mathematical Understanding, Module, Religious Character

\section{INTRODUCTION}

Mathematics subjects are strived not only to develop students' abilities in cognitive aspects (transfer of knowledge) but also to instill good moral values to students (transfer of value) (Darling-Hammond et al., 2020). However, implementing character education at the secondary school level is still a formidable challenge for Indonesian national education (Sukmayadi \& 
Choirudin, Setiawan, A., Anwar, M.S., Riyana, E., Abrori, M.S., Wahyudi. (2021). DEVELOPMENT OF QUR'AN AND HADITH-BASED MATHEMATICS MODULE FOR STUDENTS' MATHEMATICAL UNDERSTANDING AND RELIGIOUS CHARACTER. Jurnal Tatsqif, 19 (2), 114-132. https://doi.org/10.20414/itq.v19i2.4086

Yahya, 2020). Because of the non-academic achievements, the characters are still not as expected (Zakso et al., 2021). So far, character education carried out in schools is limited to particular subjects such as religion or civics.

The mandate of the Ministry of Religion towards State Islamic Universities and Madrasas throughout Indonesia regarding integrating science with religion is expected to be able to build values and morality from each student through learning the integration of science and religion (Anwar \& Elfiah, 2019; Sumarni et al., 2020). This mandate also applies to the field of mathematics, which requires learning to integrate mathematics and theology.

Religious character is one of the 18 national characters that are very important for children (Allen et al., 2015). Because religious character is a stronghold that can prevent the degradation of ethical and moral values among teenagers, the sacred character can be integrated into various subjects, especially mathematics (Chowdhury, 2016; Ernest, 2020; Genç, 2018).

Efforts to implement religious character education, especially in mathematics at the secondary school level, are not as easy as turning the palm. The reality on the ground shows this. The cultivation of religious characters in mathematics learning is still very rarely found. Even among teachers, there is still a view that mathematics and religion are two materials that do not touch each other.

In learning mathematics, most teachers use student worksheets (LKPD) which only contain abstract mathematical concepts. The LKPD presented only contains material, practice questions, and competency tests, and there is no linkage between the material and the context of values in the Qur'an and Hadith. Based on research at MTs Hidayatul Mubtadiin Dayapure, it was found that the LKPD used in the school is presented in the following form: 
Choirudin, Setiawan, A., Anwar, M.S., Riyana, E., Abrori, M.S., Wahyudi. (2021). DEVELOPMENT OF QUR'AN AND HADITH-BASED MATHEMATICS MODULE FOR STUDENTS' MATHEMATICAL UNDERSTANDING AND RELIGIOUS CHARACTER. Jurnal Tatsqif, 19 (2), 114-132. https://doi.org/10.20414/jtq.v19i2.4086

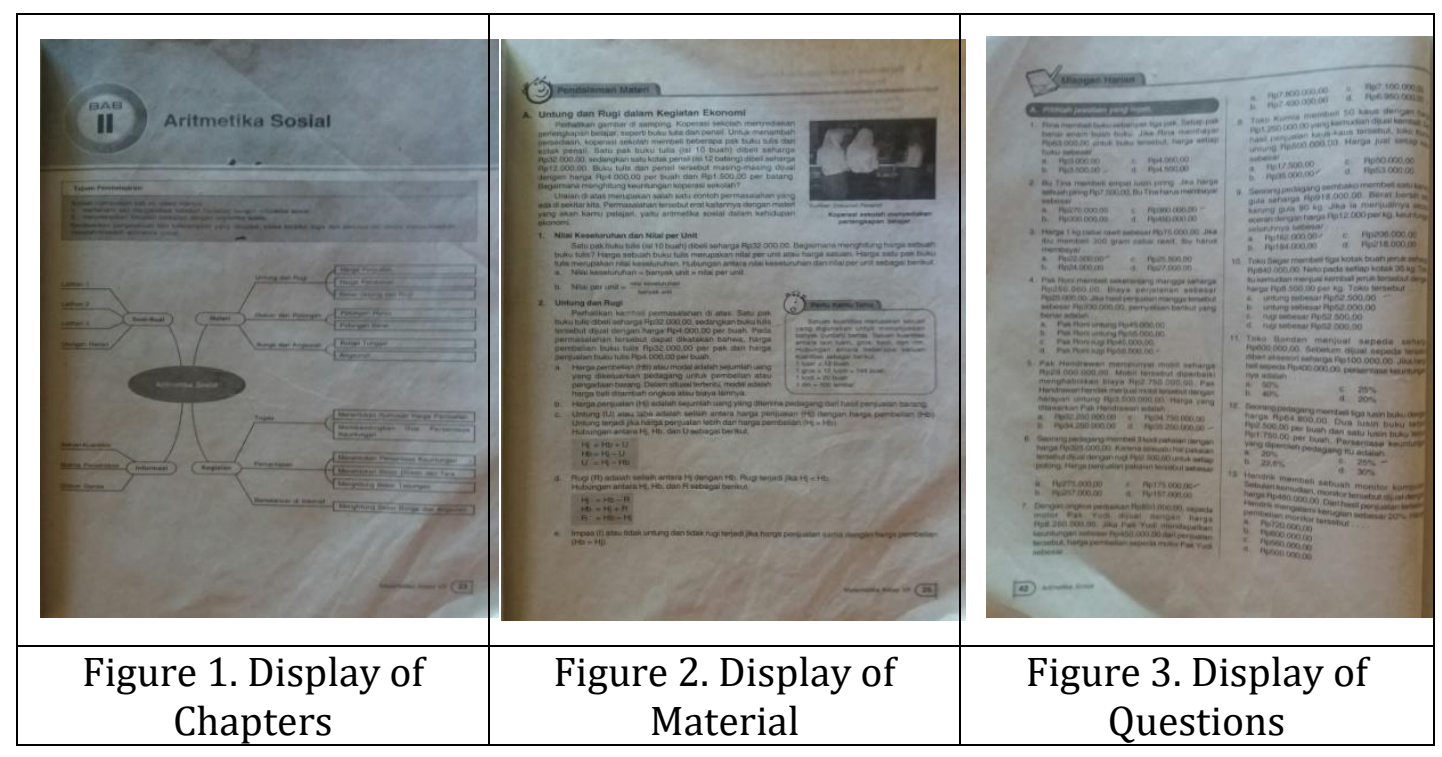

Based on the three figures, it can be seen that the LKPD design in the chapter display does not attract students' interest in learning. The LKPD only presents some learning objectives and concept maps. The core competencies, essential competencies, and achievement indicators are not written down according to the LKPD elements.

The reason is that teachers are still having problems making plans for learning mathematics in integrating religious character values in learning mathematics (Abdussakir, 2017; Abramovich et al., 2019). The child can understand the concept of fractions verbally, but the child cannot mention fractions through pictures correctly. Because childrens' learning difficulties are challenged to complete academic tasks given by the teacher at school, for this reason, this research strives to provide early services to children so that later children do not experience learning difficulties. So the integration of mathematics modules based on the Qur'an and Hadith can give the mathematical understanding and improve the students' religious character (Choirudin et al., 2020; Hariyono \& Ulia, 2020), so fundamental problems in learning mathematics can be overcome early.

Development of LKPD based on the Qur'an and Hadith has been conducted by (Anggreni, 2019; Choirudin et al., 2020; Fitriza et al., 2020; 
Choirudin, Setiawan, A., Anwar, M.S., Riyana, E., Abrori, M.S., Wahyudi. (2021). DEVELOPMENT OF QUR'AN AND HADITH-BASED MATHEMATICS MODULE FOR STUDENTS' MATHEMATICAL UNDERSTANDING AND RELIGIOUS CHARACTER. Jurnal Tatsqif, 19 (2), 114-132. https://doi.org/10.20414/itq.v19i2.4086

Hariyono \& Ulia, 2020; Mauluah et al., 2021; Novianti et al., 2021), but some of these studies have only developed a product as a medium in learning Mathematics. In addition to developing a product of teaching materials, the differences made in this study are also applied to achieve student competence, especially understanding mathematics and religious character.

Studying mathematics can help in the formation of Islamic character education because mathematics has a close relationship with the verses of the Qur'an, and the Hadith is a way of life in Islam. The LKPD that was developed was able to form Islamic character through mathematics through learning and teaching mathematics. Mathematical concepts that are relevant to the Qur'an can be conveyed to students through learning. It motivates the researchers to develop a mathematics module based on the Qur'an and Hadith that can provide mathematical understanding and improve the religious character of students in secondary schools.

\section{METHOD}

In this study, the mixed method combines research and development (R\&D) and quantitative research methods (Creswell \& Creswell, 2017). The first stage is developing mathematics teaching materials based on the Qur'an and Hadith, which are packaged in the form of modules. Furthermore, the second stage uses quantitative methods to measure the mathematical understanding of religious characters from the results of mathematics learning using a mathematics module based on the Qur'an and Hadith.

This research and development (R\&D) to develop mathematics teaching materials based on the Qur'an and Hadith, which are packaged in the form of modules. Metode penelitian kuatitatif mengukur pemahaman matematikan karakter relijius dari hasil pemebelajaran matematika using a mathematics module based on the Qur'an and Hadith. The Borg and Gall model (Benková et al., 2020; Gall et al., 2007) model has seven stages. The developing steps for a 
Choirudin, Setiawan, A., Anwar, M.S., Riyana, E., Abrori, M.S., Wahyudi. (2021). DEVELOPMENT OF QUR'AN AND HADITH-BASED MATHEMATICS MODULE FOR STUDENTS' MATHEMATICAL UNDERSTANDING AND RELIGIOUS CHARACTER. Jurnal Tatsqif, 19 (2), 114-132. https://doi.org/10.20414/jtq.v19i2.4086

mathematics module based on the Qur'an and Hadith were carried out up to the revision stage of the limited-scale test results.

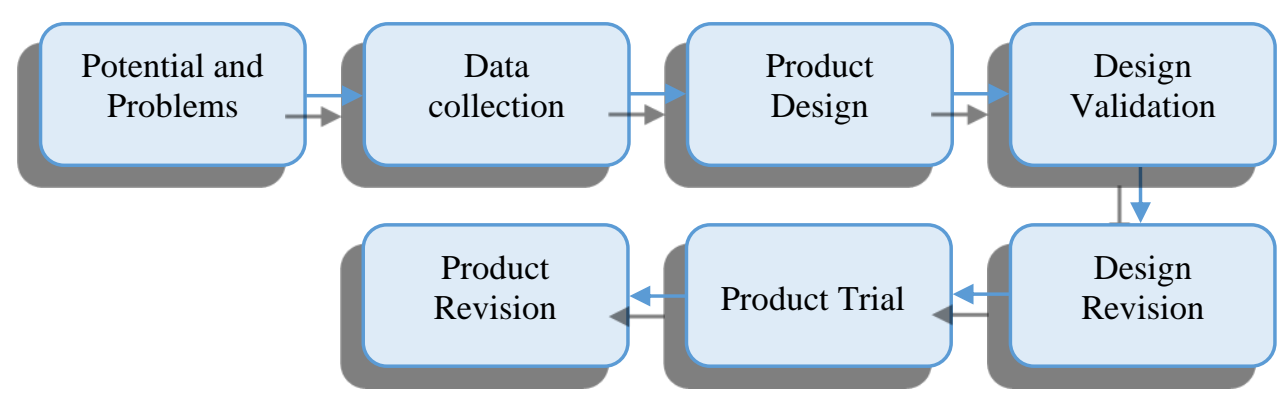

Figure 4. Borg \& Gall R\&D Model

Data collection techniques used are interviews with mathematics teachers and students to obtain initial data about the needs of mathematics learning media and their weaknesses. Informants were taken randomly the information obtained was universal, documentation was carried out to record the achievement of learning objectives in the classroom, and questionnaires were given to students to measure the feasibility of using the developed modules based on the Qur'an and Hadith (Creswell \& Creswell, 2017; Murphy \& Tosti-Kharas, 2021).

Several types of questionnaires used in data collection are needs analysis questionnaires and validation questionnaires. Validation questionnaires include media expert validation questionnaires, material expert validation questionnaires, religious expert validation questionnaires, student response questionnaires, and educator response questionnaires. The five questionnaires contain items of quality criteria regarding the development of teaching materials for mathematics modules based on the Qur'an and Hadith. The validation questionnaire uses a Likert scale consisting of 5 scores. The research instrument is in the form of a checklist.

Table. 1 Likert Scale Rating (Sugiyono, 2017)

\begin{tabular}{|c|l|c|}
\hline No & \multicolumn{1}{|c|}{ Description } & Score \\
\hline 1 & Strongly agree & Score 5 \\
\hline
\end{tabular}


Choirudin, Setiawan, A., Anwar, M.S., Riyana, E., Abrori, M.S., Wahyudi. (2021). DEVELOPMENT OF QUR'AN AND HADITH-BASED MATHEMATICS MODULE FOR STUDENTS' MATHEMATICAL UNDERSTANDING AND RELIGIOUS CHARACTER. Jurnal Tatsqif, 19 (2), 114-132. https://doi.org/10.20414/itq.v19i2.4086

\begin{tabular}{|l|l|l|}
\hline 2 & Strongly agree & Score 4 \\
\hline 3 & Doubt & Score 3 \\
\hline 4 & Disagree & Score 2 \\
\hline 5 & Strongly disagree & Score 1 \\
\hline
\end{tabular}

Analysis of teaching materials quality using the Guttman scale (Reynolds et al., 2020). The data generated from the questionnaire on the quality of teaching materials were then processed and analyzed using quantitative descriptive. This is done to determine the feasibility of the Al-Qur'an and Hadith-based mathematics module and the response of students to the teaching materials developed.

Table. 2 Achievement Level Qualification

\begin{tabular}{|c|c|}
\hline Assessment & Criteria Interpretation \\
\hline $81 \%<x \leq 100 \%$ & Very Feasible \\
\hline $61 \%<x \leq 80 \%$ & Feasible \\
\hline $41 \%<x \leq 60 \%$ & Enough Feasible \\
\hline $21 \%<x \leq 40 \%$ & Not Feasible \\
\hline
\end{tabular}

\section{FINDINGS AND DISCUSSION}

\section{Development of Qur'an and Hadith-Based Mathematics Module}

This study succeeded in developing teaching materials for mathematics modules based on the Qur'an and Hadith for seventh-grade students of SMP/MTs on fractional numbers. There are four discussion sub-chapters in this Qur'an and Hadith-based mathematics module: fractional numbers, fractional arithmetic operations, recognizing decimal numbers, and calculating decimal fraction operations.

The initial step taken by researchers in planning the initial product was to conduct a needs analysis at MTs Hidayatul Mubtadiin Dayamurni. The aim was to find out information in the field by conducting interviews with mathematics teachers. The results obtained that in the learning process using scientific learning methods and group learning. The teaching materials 
Choirudin, Setiawan, A., Anwar, M.S., Riyana, E., Abrori, M.S., Wahyudi. (2021). DEVELOPMENT OF QUR'AN AND HADITH-BASED MATHEMATICS MODULE FOR STUDENTS' MATHEMATICAL UNDERSTANDING AND RELIGIOUS CHARACTER. Jurnal Tatsqif, 19 (2), 114-132. https://doi.org/10.20414/jtq.v19i2.4086

used in education are worksheets and printed books, other media such as LCDs, and objects adapted to the subject matter in the surrounding environment. The results of the needs analysis questionnaire for students showed that some students were not interested in learning mathematics. Some of the factors that cause it are easy to feel bored, the material is difficult to understand, there are no exciting pictures, do not like to count, do not associate mathematics with the Qur'an and Hadith.

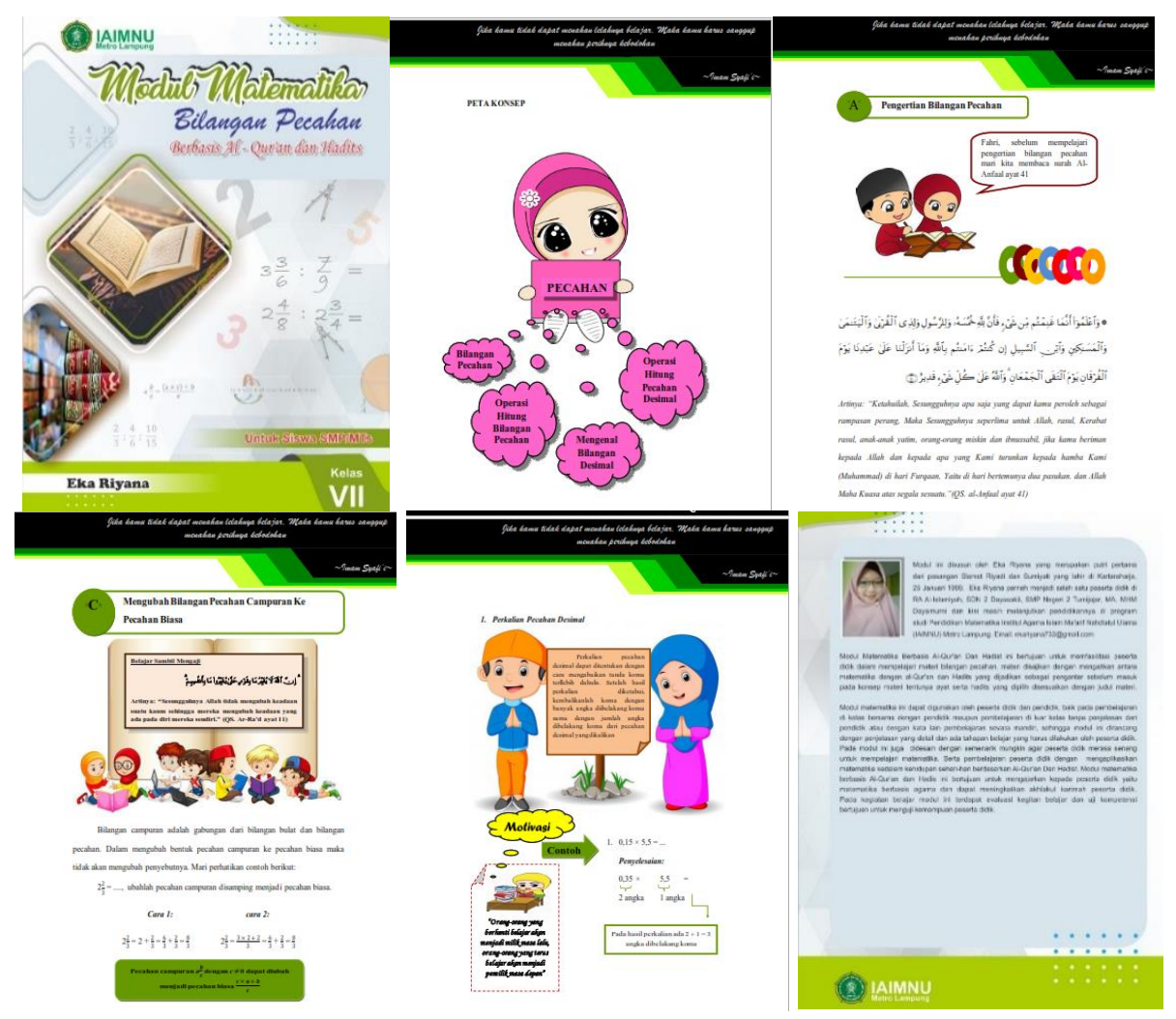

Figure 5. Qur'an and Hadith-Based Mathematics Module

Based on the needs analysis, the steps taken are collecting supporting references to make a product in the form of a mathematics module based on the Qur'an and Hadith. The researchers' stages were designing the module cover, introduction, table of contents, module description, instructions for use, concept maps, basic knowledge, fundamental skills, material description, evaluation, glossary, and bibliography. These stages are made through Microsoft Word except for the cover made through Corel Draw. The 
Choirudin, Setiawan, A., Anwar, M.S., Riyana, E., Abrori, M.S., Wahyudi. (2021). DEVELOPMENT OF QUR'AN AND HADITH-BASED MATHEMATICS MODULE FOR STUDENTS' MATHEMATICAL UNDERSTANDING AND RELIGIOUS CHARACTER. Jurnal Tatsqif, 19 (2), 114-132. https://doi.org/10.20414/itq.v19i2.4086

material is made by integrating fractional number material with verses from the Qur'an and Hadith.

Furthermore, the development of the Qur'an and Hadith-based mathematics module went through the validation stages of the module and trials. The validators of this Qur'an and Hadith-based mathematics module consist of validators from media experts, material experts, and Islamic religious experts.

In the media expert assessment stage, the researcher uses one validator lecturer. The validator provides an assessment by filling out the assessment questionnaire sheet that has been provided with a rating scale of $1,2,3,4$, to 5. The assessment questionnaire sheet contains module size, module cover design, and module content design consisting of 26 statements to be assessed. The results of the media expert's assessment are presented in the following table:

Table. 3 Media Expert Validation Results

\begin{tabular}{lcccc}
\hline \multicolumn{1}{c}{ Aspect } & $\begin{array}{c}\text { Total Each } \\
\text { Aspect }\end{array}$ & $\begin{array}{c}\text { Score } \\
\text { Maximum }\end{array}$ & $\begin{array}{c}\text { Score } \\
(\%)\end{array}$ & Description \\
\hline $\begin{array}{l}\text { Module Size } \\
\text { Module Cover }\end{array}$ & 10 & 10 & $100 \%$ & Very Feasible \\
Design & 58 & 60 & $97 \%$ & Very Feasible \\
Module Content & 52 & 60 & $87 \%$ & Very Feasible \\
Design & & & \\
Total number & & & 120 & \\
Maximum Score & & \multicolumn{2}{c}{$92 \%$} & \\
Score (\%) & & \multicolumn{3}{c}{ Very Feasible } \\
Information & & &
\end{tabular}

The assessment results by media experts in module size obtained a score of 10 from a maximum score of 10 . The percentage is $100 \%$ with very decent criteria. Then for the module cover design aspect, the score is 58 from a top score of 60 , and the percentage gain is $97 \%$ (very decent). The module's content design, which is to get 52 out of 60 , the maximum score of 
Choirudin, Setiawan, A., Anwar, M.S., Riyana, E., Abrori, M.S., Wahyudi. (2021). DEVELOPMENT OF QUR'AN AND HADITH-BASED MATHEMATICS MODULE FOR STUDENTS' MATHEMATICAL UNDERSTANDING AND RELIGIOUS CHARACTER. Jurnal Tatsqif, 19 (2), 114-132. https://doi.org/10.20414/jtq.v19i2.4086

$87 \%$, is categorized as very feasible. Thus, the total number of assessments obtained is 120 with a top score of 130 and a percentage of $92 \%$, then the module is declared very suitable for use.

The material expert validator assesses the product by filling out the assessment questionnaire sheet that the researcher has provided. The aspect that is set is the aspect of content feasibility which consists of 26 statements filled out by one material expert validator. The total score obtained is 116 with a maximum score of 130 , so the percentage is $89 \%$ in the very feasible category. So it can be seen that the material in the module is possible to use. The results of the material expert assessment are presented in the following table:

Table. 4 Material Expert Validation Results

\begin{tabular}{|c|c|c|c|c|}
\hline Aspect & $\begin{array}{l}\text { Total Each } \\
\text { Aspect }\end{array}$ & $\begin{array}{l}\text { Score } \\
\text { Maximum }\end{array}$ & $\begin{array}{l}\text { Score } \\
(\%)\end{array}$ & Description \\
\hline $\begin{array}{ll}\begin{array}{l}\text { Content } \\
\text { aspect }\end{array} & \text { feasibility } \\
\end{array}$ & 116 & 130 & $89 \%$ & $\begin{array}{l}\text { Very } \\
\text { Feasible }\end{array}$ \\
\hline
\end{tabular}

Religious experts assessed the aspects assessed, namely the quality of content and language aspects contained 22 statements evaluated in the assessment questionnaire sheet. The assessment results obtained the total number of each aspect 102 with a maximum score of 110 with a percentage gain of $93 \%$ (very feasible). The quality of the content obtained a score of 68 from a top score of 70 . The percentage is $97 \%$ very achievable criterion. For the language aspect, the score is 34 out of 40 , and the ratio is $85 \%$, categorized as very feasible.

The assessment questionnaire sheet for the researcher's teacher responses used one mathematics teacher at MTs, Hidayatul Mubtadiin Dayamurni. The assessment results found that the category was feasible-an overall percentage acquisition of $95 \%$ with details of 200 with a maximum score of 210. After the product was validated by media experts, religious 
Choirudin, Setiawan, A., Anwar, M.S., Riyana, E., Abrori, M.S., Wahyudi. (2021). DEVELOPMENT OF QUR'AN AND HADITH-BASED MATHEMATICS MODULE FOR STUDENTS' MATHEMATICAL UNDERSTANDING AND RELIGIOUS CHARACTER. Jurnal Tatsqif, 19 (2), 114-132. https://doi.org/10.20414/itq.v19i2.4086

experts, and material experts, the teaching materials were used. Educators assessed the effect and then tested on students at MTs Hidayatul Mubtadiin Dayamurni,

Based on the results of the assessment of the material, religious, and media expert validators above. It can be concluded that learning mathematics using teaching materials for mathematics modules based on the Qur'an and Hadith is very feasible and can be used as a resource in learning mathematics.

The last stage is evaluation. At this stage, it is carried out to see how learning mathematics modules based on the Qur'an and Hadith affect students' religious understanding and competence. In the pre-test and posttest recapitulation tables, in general, there is an increase in the score for each student. However, this increase should be rechecked for its significance level by using the n-gain test. The average n-gain obtained is 0.55 . It can be concluded that the increase in student scores is in the moderate category because in the interval 0.3-0.7.

The results of the n-Gain test show that the increase in students' mathematical understanding after studying the material is still at a moderate level. It means that the growth has not been too significant. Some things that might be the cause are: 1) The questions given to students are in the form of non-routine story questions, 2) Students are still having problems understanding story questions, 3) Characteristics of fractional material that have a high level of difficulty, 4) The prerequisite abilities are still not fully mastered (multiplication and division).

Self-assessment sheets measure students' religious character after students learn mathematics modules based on the Qur'an and Hadith. The results of the self-assessment are presented in the following table 5.

Table. 5 Indicators Religious Character

\begin{tabular}{lc}
\hline Statement Indicator & Percentage \\
\hline Admire and be grateful as God's creatures: &
\end{tabular}


Choirudin, Setiawan, A., Anwar, M.S., Riyana, E., Abrori, M.S., Wahyudi. (2021). DEVELOPMENT OF QUR'AN AND HADITH-BASED MATHEMATICS MODULE FOR STUDENTS' MATHEMATICAL UNDERSTANDING AND RELIGIOUS CHARACTER. Jurnal Tatsqif, 19 (2), 114-132. https://doi.org/10.20414/jtq.v19i2.4086

\begin{tabular}{lc}
\hline Statement Indicator & Percentage \\
\hline $\begin{array}{l}\text { I am thankful for having the opportunity to study } \\
\text { mathematics. }\end{array}$ & $100 \%$ \\
$\begin{array}{l}\text { I will study mathematics even harder because mathematics } \\
\text { is also the essence of Allah SWT }\end{array}$ & $90 \%$ \\
Feel God's power with all his creations in the world: & \\
After learning mathematics modules based on the Qur'an & \\
and Hadith, I am more and more convinced of the truth of & $100 \%$ \\
the Qur'an & \\
After learning mathematics modules based on the Qur'an & $95 \%$ \\
and Hadith, I am more confident in the power of Allah SWT & \\
Admire God's power, who has created various universes. & \\
Admire God's greatness because religion is the source of the & $85 \%$ \\
regularity of life public. & \\
Admire God's greatness through various subjects. & $90 \%$ \\
\hline
\end{tabular}

Based on the results of the assessment of the students' religious character, learning using a mathematics module based on the Qur'an and Hadith can shape students' religious attitudes, such as being grateful for being allowed to learn mathematics and being more active because of mathematics. After studying the mathematics module based on the Qur'an and Hadith increasingly convinced of the truth of the Qur'an and believed in the power of Allah. Admire God's greatness through learning mathematics.

\section{Discussion}

Development of communication skills in counting using numbers, especially infractions, namely ordinary fractions, mixed fractions, and decimal fractions, can explain and solve problems in everyday life. The assessment results showed that children had difficulty operating, counting particles, recognizing decimal numbers, and calculating fractions.

Teaching materials are a means to facilitate the delivery of material to students and support the learning process. In making teaching materials, an educator must also pay attention to the students' ability, age, and psychological level to make appropriate teaching materials for them. 
Choirudin, Setiawan, A., Anwar, M.S., Riyana, E., Abrori, M.S., Wahyudi. (2021). DEVELOPMENT OF QUR'AN AND HADITH-BASED MATHEMATICS MODULE FOR STUDENTS' MATHEMATICAL UNDERSTANDING AND RELIGIOUS CHARACTER. Jurnal Tatsqif, 19 (2), 114-132. https://doi.org/10.20414/itq.v19i2.4086

Especially learning mathematics is considered difficult and tedious by almost all students.

MTs Hidayatul Mubtadiin is known that the media used in learning mathematics uses LCD media and objects adapted to the subject matter in the surrounding environment. For example, in the subject matter of the opportunity for educators to use dice and coins as learning media so that students are easier to find, understand, and remember. The textbooks used are only worksheets and printed books or textbooks compiled by the Ministry of Education and Culture. Teaching materials that can be used for learning mathematics are worksheets and printed books. Still, many other teaching materials can be used for learning mathematics, namely handouts, textbooks, fashion (mockups), posters, brochures, and modules.

The integration of mathematics with religion is not just looking for religious arguments for mathematics (Leach, 2013), nor is the process of Islamizing mathematics, but how mathematics can be an intermediary for students and their environment to get closer to Allah (Shamsudin \& Alinor, 2014).

The Qur'an and Hadith do not distinguish between religious knowledge and general knowledge (Akhavanmoghadam, 2021; Anwar \& Elfiah, 2019; Mabud, 2016). What is in the Qur'an is science. The division of spiritual knowledge and available science results from human conclusions that identify science based on its object and study. There are several verses of the Qur'an and the Hadith of the Prophet which show that there is no difference between religious knowledge and general knowledge, one of which is explained in the Qur'an surah Al-Qashash verse 77.

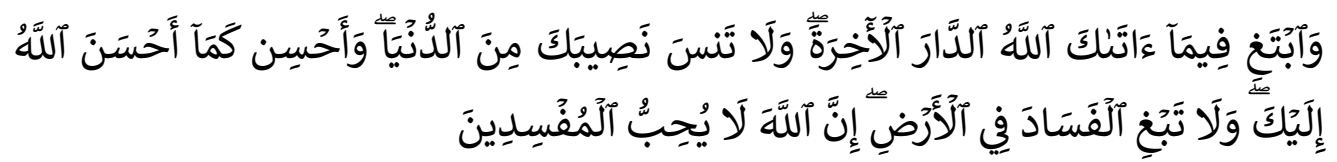

77. But seek, through that which Allah has given you, the home of the hereafter; and [yet], do not forget your share of the world. Moreover, do good as Allah has done well to you. Moreover, desire is not corruption in 
Choirudin, Setiawan, A., Anwar, M.S., Riyana, E., Abrori, M.S., Wahyudi. (2021). DEVELOPMENT OF QUR'AN AND HADITH-BASED MATHEMATICS MODULE FOR STUDENTS' MATHEMATICAL UNDERSTANDING AND RELIGIOUS CHARACTER. Jurnal Tatsqif, 19 (2), 114-132. https://doi.org/10.20414/jtq.v19i2.4086

the land. Indeed, Allah does not like corrupters."(Departemen Agama RI, 2015)

Every Muslim is recommended to achieve balanced happiness between this world and the hereafter. One way that can be done is by balancing general science, especially mathematics, with religious knowledge. In everyday life, mathematics has a significant role. Every activity is closely related to mathematics, such as clocks, symbols of time and units of time, calculating electricity bills, calculating land and building taxes, calculating profit and loss results in the trading process. However, it is not uncommon for students to think that mathematics is difficult and tedious. One thing that can attract students' interest in learning is by using teaching materials such as modules. Modules are teaching materials that have characteristics, namely the principle of independent learning. Modules based on the Qur'an and Hadith are expected to foster the divinity of students. The teaching materials of this module will also break the assumption that most people assume that there is no relationship between mathematics and religious knowledge (Qur'an) when in fact, mathematics is a science that is discussed in the Qur'an and Hadith, of which is about fractions. The purpose of this study is to integrate fractional numbers with the Qur'an and Hadith. The integration of mathematics with the Qur'an and Hadith can help educators to teach religion-based mathematics that is sourced from the Qur'an and Hadith and can improve the morals of students, especially in the matter of fractions.

Mathematical understanding is a vital mathematical ability possessed by students in learning mathematics. This ability becomes an essential basis for thinking in solving mathematical problems and real-life problems. In addition, mathematical understanding strongly supports the development of other mathematical skills. The use of visual media in learning mathematics modules based on the Qur'an and Hadith can help students develop their mathematical understanding because they bring the representation of a new fact or procedure closer to an existing network by using semi-concrete 
Choirudin, Setiawan, A., Anwar, M.S., Riyana, E., Abrori, M.S., Wahyudi. (2021). DEVELOPMENT OF QUR'AN AND HADITH-BASED MATHEMATICS MODULE FOR STUDENTS' MATHEMATICAL UNDERSTANDING AND RELIGIOUS CHARACTER. Jurnal Tatsqif, 19 (2), 114-132. https://doi.org/10.20414/itq.v19i2.4086

objects. Submission of mathematics with an understanding and meaning approach provides several logical consequences: supporting memory, reducing the amount that must be remembered, increasing transfer, and influencing students' beliefs about mathematics.

The results also show that Islamic values are integrated with elementary mathematics learning (Fahyuni et al., 2020; Muslimin et al., 2020). In this case, the concept of fractions can develop students' religious character. Before students understand the concept of fractions, students are directed to verses of the Qur'an that discuss fractions. It is done to show that Islam and mathematics have a close relationship. There is no dichotomy of science; knowledge is born from one's awareness as a servant of Allah when responding to his creation (Zaharin \& Pallotta-Chiarolli, 2020). Thus, the spread of religion is not only emphasized on the doctrinal aspect but with a scientific or scientific approach in faith.

McKay \& Whitehouse (2015) considered that the effort to overcome the moral decadence of existing lessons is not by increasing the hours of religious studies. In the Qur'an, Muslims are required to read nature. So all the tasks that are currently developing are in principle the same as the lessons of monotheism. Because religious values have been absorbed in other sciences, what is needed now is to straighten the orientation of the learning process. It takes the hard work of teachers to explore the nature of Islam contained in general subjects.

\section{CONCLUSIONS AND SUGGESTIONS}

Based on the discussion in the development of a mathematics module based on the Qur'an and Hadith is carried out by the Borg \& Gall development steps, which are limited to the seventh stage, including potential problems, data collection, product design, design validation. Design revisions, product trials, and product revisions. The final result obtained is a mathematics module based on the Qur'an and Hadith. The verses of the 
Choirudin, Setiawan, A., Anwar, M.S., Riyana, E., Abrori, M.S., Wahyudi. (2021). DEVELOPMENT OF QUR'AN AND HADITH-BASED MATHEMATICS MODULE FOR STUDENTS' MATHEMATICAL UNDERSTANDING AND RELIGIOUS CHARACTER. Jurnal Tatsqif, 19 (2), 114-132. https://doi.org/10.20414/jtq.v19i2.4086

Qur'an contained in the fractional number material, namely, QS. Saba' verse 45, QS. Al-Anfaal verse 41, QS. Al-Muzzammil verses 3, 4, and 20, and Surah an-Nisa verses $11,12,25$, and 176. In comparison, the Hadith contained in the fractional number material is the Hadith which explains the virtues of people who are unique in their prayers, the virtues of evening prayers, the purity of zakat mal, the integrity of marriage, and the goodness of QS. AlIkhlas. The feasibility of the Qur'an and Hadith-based mathematics module on the fractional number material based on the assessment of the media expert got a score of $92 \%$ in the very feasible category. The evaluation from the material expert got a score of $89 \%$ in every possible class. The assessment of the religious expert got a score of $93 \%$ with a very decent type.

In learning using a mathematics module based on the Qur'an and Hadith, it can improve students' mathematical understanding at a moderate level. Learning using a mathematics module based on the Qur'an and Hadith can shape students' religious attitudes. Based on the results of the research, it is recommended for further researchers to improve further their mastery of integrating verses of the Qur'an and Hadith with the material, and not only develop one subject but also on other subjects.

\section{ACKNOWLEDGMENT}

Thanks to Institut Agama Islam Ma'rif NU (IAIMNU) Metro Lampung through the Institute for Research and Community Service (LP2M) and MTs Hidayatul Mubtadiin Dayamurni, who have supported the implementation of this study.

\section{REFERENCES}

Abdussakir, A. (2017). Internalisasi Nilai-nilai Islami dalam Pembelajaran Matematika dengan Strategi Analogi. Prosiding SI MaNIs (Seminar Nasional Integrasi Matematika Dan Nilai-Nilai Islami), 1(1), 659-665. 
Choirudin, Setiawan, A., Anwar, M.S., Riyana, E., Abrori, M.S., Wahyudi. (2021). DEVELOPMENT OF QUR'AN AND HADITH-BASED MATHEMATICS MODULE FOR STUDENTS' MATHEMATICAL UNDERSTANDING AND RELIGIOUS CHARACTER. Jurnal Tatsqif, 19 (2), 114-132. https://doi.org/10.20414/itq.v19i2.4086

Abramovich, S., Grinshpan, A. Z., \& Milligan, D. L. (2019). Teaching Mathematics through Concept Motivation and Action Learning. Education Research International, 2019, e3745406. https://doi.org/10.1155/2019/3745406

Akhavanmoghadam, Z. (2021). The Necessity of Methodological Patterns in the Qur'an Based on "Comprehensiveness." International Journal of Multicultural and Multireligious Understanding, 8(4).

Allen, L., Kelly, B. B., Success, C. on the S. of C. B. to A. 8: D. and B. the F. for, Board on Children, Y., Medicine, I. of, \& Council, N. R. (2015). Child Development and Early Learning. In Transforming the Workforce for Children Birth Through Age 8: A Unifying Foundation. National Academies Press (US).

https://www.ncbi.nlm.nih.gov/books/NBK310550/

Anggreni, F. (2019). Integrasi Al-Quran pada Mata Pelajaran Matematika terhadap Kemampuan Siswa. At- Tarbawi, 6(1), 42-53. https://doi.org/10.32505/tarbawi.v11i1.1029

Anwar, S., \& Elfiah, R. (2019). Science and Religious Integration (Implications for the Development at UIN Raden Intan Lampung). Journal of Physics: Conference Series, 1155, 012095. https://doi.org/10.1088/17426596/1155/1/012095

Benková, E., Gallo, P., Balogová, B., \& Nemec, J. (2020). Factors Affecting the Use of Balanced Scorecard in Measuring Company Performance. Sustainability, 12(3), 1178. https://doi.org/10.3390/su12031178

Choirudin, C., Ningsih, E. F., Anwar, M. S., Choirunnisa, A., \& Maseleno, A. (2020). The Development of Mathematical Students Worksheet Based on Islamic Values Using Contextual Approach. International Journal on Emerging Mathematics Education, 3(2), 152-161. https://doi.org/10.12928/ijeme.v3i2.13286 
Choirudin, Setiawan, A., Anwar, M.S., Riyana, E., Abrori, M.S., Wahyudi. (2021). DEVELOPMENT OF QUR'AN AND HADITH-BASED MATHEMATICS MODULE FOR STUDENTS' MATHEMATICAL UNDERSTANDING AND RELIGIOUS CHARACTER. Jurnal Tatsqif, 19 (2), 114-132. https://doi.org/10.20414/jtq.v19i2.4086

Chowdhury, M. (2016). Emphasizing Morals, Values, Ethics, And Character Education In Science Education And Science Teaching. The Malaysian Online Journal of Educational Science, 4(2).

Creswell, J. W., \& Creswell, J. D. (2017). Research Design: Qualitative, Quantitative, and Mixed Methods Approaches. SAGE Publications.

Darling-Hammond, L., Flook, L., Cook-Harvey, C., Barron, B., \& Osher, D. (2020). Implications for educational practice of the science of learning and development. Applied Developmental Science, 24(2), 97-140. https://doi.org/10.1080/10888691.2018.1537791

Departemen Agama RI. (2015). Al-Qur'an dan Terjemahannya. CV Darussunah.

Ernest, P. (2020). Mathematics, ethics and purism: An application of MacIntyre's virtue theory. Synthese. https://doi.org/10.1007/s11229020-02928-1

Fahyuni, E. F., Wasis, W., Bandono, A., \& Arifin, M. B. U. B. (2020). Integrating Islamic Values and Science for Millennial Studentsâ€TM Learning on Using Seamless Mobile Media. Jurnal Pendidikan IPA Indonesia, 9(2), 231-240. https://doi.org/10.15294/jpii.v9i2.23209

Fitriza, R., Putra, M. S., \& Samad, D. (2020). Pengembangan Lembar Kerja Peserta Didik Berwawasan Al-Qur'an Dan Budaya Minangkabau Dalam Pembelajaran Matematika Kelas X. AKSIOMA: Jurnal Program Studi Pendidikan Matematika, 9(4), 1159-1171. https://doi.org/10.24127/ajpm.v9i4.3212

Gall, M. D., Gall, J. P., \& Borg, W. R. (2007). Educational Research: An Introduction. Pearson/Allyn \& Bacon.

Genç, M. F. (2018). Values Education or Religious Education? An Alternative View of Religious Education in the Secular Age, the Case of Turkey. $\begin{array}{lll}\text { Education } & \text { Sciences, } & \text { 8(4), }\end{array}$ https://doi.org/10.3390/educsci8040220 
Choirudin, Setiawan, A., Anwar, M.S., Riyana, E., Abrori, M.S., Wahyudi. (2021). DEVELOPMENT OF QUR'AN AND HADITH-BASED MATHEMATICS MODULE FOR STUDENTS' MATHEMATICAL UNDERSTANDING AND RELIGIOUS CHARACTER. Jurnal Tatsqif, 19 (2), 114-132. https://doi.org/10.20414/itq.v19i2.4086

Hariyono, M., \& Ulia, N. (2020). Development Teaching Materials of Mathematics Basic Concepts Based on Internalization of Islamic Value to Increasing Concept Understanding Ability. Jurnal Pendidikan Dasar : Jurnal Tunas Nusantara, 2(1).

Leach, J. (2013). Mathematics and Religion. In A. L. C. Runehov \& L. Oviedo (Eds.), Encyclopedia of Sciences and Religions (pp. 1214-1219). Springer Netherlands. https://doi.org/10.1007/978-1-4020-82658_1582

Mabud, S. A. (2016). Integrating Islamic And Modern KnowledgePhilosophical Concepts And Their Practical Applications. Batusangkar International Conference, 28.

Mauluah, L. M., Marsigit, M., \& Wangid, M. N. (2021). Rancangan Lembar Kerja Matematika SD Berbasis Islamic Environmental Ethics. Muallimuna: Jurnal Madrasah Ibtidaiyah, 6(2), 70-82. https://doi.org/10.31602/muallimuna.v6i2.4525

McKay, R., \& Whitehouse, H. (2015). Religion and Morality. Psychological Bulletin, 141(2), 447-473. https://doi.org/10.1037/a0038455

Murphy, W., \& Tosti-Kharas, J. (2021). Handbook of Research Methods in Careers. Edward Elgar Publishing.

Muslimin, M., Putri, R. I. I., Zulkardi, Z., \& Aisyah, N. (2020). Learning Integers With Realistic Mathematics Education Approach Based On Islamic Values. Journal on Mathematics Education, 11(3), 363-384. https://doi.org/10.22342/jme.11.3.11721.363-384

Novianti, Hartoyo, A., \& Nursangaji, A. (2021). Pengembangan Bahan Ajar Bersumber Al-Qur'an Berbentuk Modul Pada Materi Fungsi Kelas X. Authentic Research On Mathematics Education (JARME), 3(2). https://doi.org/10.37058/jarme.v3i2.3357

Reynolds, C. R., Allen, D. N., \& Altmann, R. A. (2020). Mastering Modern Psychological Testing: Theory and Methods. Springer Nature. 
Choirudin, Setiawan, A., Anwar, M.S., Riyana, E., Abrori, M.S., Wahyudi. (2021). DEVELOPMENT OF QUR'AN AND HADITH-BASED MATHEMATICS MODULE FOR STUDENTS' MATHEMATICAL UNDERSTANDING AND RELIGIOUS CHARACTER. Jurnal Tatsqif, 19 (2), 114-132. https://doi.org/10.20414/jtq.v19i2.4086

Shamsudin, A. F., \& Alinor, M. (2014). Development of Ethno-mathematics of Al-Qur'an, Al-Hadith, and Jawi Scripts for Computer Security. Islamic Perspectives Relating to Business, Arts, Culture and Communication. Proceedings of the 1st ICIBACC, Singapore.

Sugiyono. (2017). Metode Penelitian Kuantitatif, Kualitatif, dan R\&D. CV. Alfabeta.

Sukmayadi, V., \& Yahya, A. H. (2020). Indonesian Education Landscape and the 21st Century Challenges. Journal of Social Studies Education Research, 11(4), 219-234.

Sumarni, W., Faizah, Z., Subali, B., Wiyanto, W., \& Ellianawati, E. (2020). The urgency of religious and cultural science in STEM education: A metadata analysis. International Journal of Evaluation and Research in Education (IJERE), $9(4)$ 1045. https://doi.org/10.11591/ijere.v9i4.20462

Zaharin, A. A. M., \& Pallotta-Chiarolli, M. (2020). Countering Islamic conservatism on being transgender: Clarifying Tantawi's and Khomeini's fatwas from the progressive Muslim standpoint. International Journal of Transgender Health, 21(3), 235-241. https://doi.org/10.1080/26895269.2020.1778238

Zakso, A., Agung, I., Susanto, A. B., \& Capnary, M. C. (2021). The Effect of Strengthening Character Education on Tolerance Increasing and Development of Pancasila Students in Border Area: Case of West Kalimantan Province. Academic Journal of Interdisciplinary Studies, 10(5), 232. https://doi.org/10.36941/ajis-2021-0136 